Borneo Journal of Sciences and Technology, Volume (1), Issue (1), Pages: 21-28

DOI: https://doi.org/10.35370/bjost.2019.1.1-05

e-ISSN: 2672-7439

(C) 2018, UCTS Publisher.

Submitted: 11October 2018

Accepted: 15 October 2018

Published: 31 January 2019

\title{
Assessment of Water Quality and Sedimentary Nutrient Status of Tumpat Mangrove Swamp Forest at Kelantan Delta, Malaysia
}

${ }^{1,3}$ Mohammed Abdus Salam ${ }^{*},{ }^{2}$ Siti Fazlin Binti Othman, ${ }^{1}$ Md. Shohel Khan, ${ }^{1}$ Mohammad Mahbub Kabir, ${ }^{3}$ Aweng E R, ${ }^{4} \mathrm{Md}$. Abdul Khaleque

${ }^{1}$ Department of Environmental Science and Disaster Management, Faculty of Science, Noakhali Science and Technology University, Noakhali-3814, Bangladesh.

${ }^{2}$ Natural Science Program, Faculty of Earth Science, University Malaysia Kelantan, 17600 Jeli, Malaysia

${ }^{3}$ Sustainability Science Program, Faculty of Earth Science, University Malaysia Kelantan, 17600 Jeli, Malaysia

${ }^{4}$ Department of Environmental Management, Faculty of Environmental Science and Management, Independent University, Bangladesh, Bashundhra R/A, Dhaka-1229, Bangladesh

\begin{abstract}
An assessment of water quality and sediment nutrients has been carried out in Tumpat mangrove swamp forest located at Kelantan Delta in Malaysia. This mangrove delta is considered as very important to reduce the destruction of any natural disaster. Tumpat mangrove delta is possessed with several islands. Among them five islands situated at different locations started from inland edge to seaward were selected for present study. Different anthropogenic activities such as dumping of industrial and domestic effluent may contribute to degrade the water quality and sediments nutrient status. A total of 90 (water and sediment) samples 45 from each category were collected from 5 randomly selected islands. The aims of this study were to assess the water quality and sedimentary nutrients status and establish their relationship to find out the nutrient's dynamic of Tumpat Mangrove Forest. The samples were tested in the laboratory to determine the water parameters and nutrient status. The results revealed that the mean concentration of DO, electric conductivity, $\mathrm{pH}$ was $4.67 \pm 0.13 \mathrm{mg} / \mathrm{L}, 20.49 \pm 4.71 \mu \mathrm{S} / \mathrm{cm}$ and $8.32 \pm 0.06$ and ranged from 4.47-4.87 mg/L, 14.21-28.67 $\mu \mathrm{s} / \mathrm{cm}$ and 8.24-8.42 at Palau Bedal (PB), Palau Layang-layang (PL), Palau Kambing (PK), Palau Mas (PS) and Palau Tujuh (PT) islands, respectively. The mean concentration of BOD, COD and oil and grease $(\mathrm{OG})$ were $1.09 \pm 0.13 \mathrm{mg} / \mathrm{L}, 70.93 \pm 25.21 \mathrm{mg} / \mathrm{L}$ and $91.77 \pm 68.16 \mathrm{mg} / \mathrm{L}$ and the values were ranged from $0.9-1.25 \mathrm{mg} / \mathrm{L}, 44.33-120 \mathrm{mg} / \mathrm{L}$ and $18.67-205.71 \mathrm{mg} / \mathrm{L}$ at $\mathrm{PB}$, PL, PK, PS and PT islands, respectively. Mean percentage of sediment nutrients such as N, P, K and Ca were $0.41 \pm 0.04 \%, 4.66 \pm 2.09 \mathrm{mg} / \mathrm{L}$, $50.61 \pm 10.58 \mathrm{mg} / \mathrm{L}$ and $83.15 \pm 11.78 \mathrm{mg} / \mathrm{L}$ and ranged from $0.36-0.49 \%, 2.14-8.33 \mathrm{mg} / \mathrm{L}, 34.25-69.4 \mathrm{mg} / \mathrm{L}$ and $66.71-104.18 \mathrm{mg} / \mathrm{L}$ at PB, PL, PK, PS and PT islands, respectively. The highest $\mathrm{N}$ value was found in PT Island nearest to the coastal area. Deposition of litter from human settlement and fish chip factory might be the reason for higher $\mathrm{N}$ value. The trend of the $\mathrm{P}$ concentration for the study area was decreased from seaward to inland edge. Correlation analysis indicated the positive relationship between K: OG ( $r=0.678)$ and $\mathrm{Mg}$ : OG $(r=0.721)$ but $\mathrm{Ca}$ : temperature $(\mathrm{r}=-0.705)$ was negatively correlated. It is presumed that different concentrations of physico-chemical properties might be influenced for sedimentary nutrients dynamic at study area. Moreover, the sediment of the study area was not dynamic because most of the nutrient $(\mathrm{P}, \mathrm{K}$, and $\mathrm{Mg}$ ) were influenced by the concentration of OG values.
\end{abstract}

Keywords: Water Quality, Ecosystem, Nutrients, Coastal Area, Mangrove Forest

\section{INTRODUCTION}

Mangrove swamp forest is one of the most diversified ecosystems in wetland [1]. The high diversity of species in mangrove swamp ecosystem is giving emphasized for maintain its ecosystem without human disturbances. The global mangrove distribution is getting loss in area estimated at 0.16 to $0.39 \%$ per year [2], [3]. The productivity of mangrove ecosystem depends on several environmental factors i.e. soil condition, climate

Corresponding Author: Mohammed Abdus Salam, Noakhali Science and Technology University, Tel: +88-01917635348, E-mail:

s_salam1978@yahoo.com 


\section{Assessment of Water Quality and Sedimentary Nutrient Status of Tumpat Mangrove Swamp Forest at Kelantan Delta, Malaysia}

change, water quality, rainfall and other relevant factors [4]. Mangrove forest encompasses a group of trees or suburbs that grow in tidal waters along tropical and subtropical coastlines. The mangrove ecosystem provides important services such as food, wood, chemical pharmaceutical production and other aesthetic values and also offers such critical ecological functions as coastal protection, land stabilization, water purification and $\mathrm{CO}_{2}$ fixation [5], [6]. Nutrient availability is also one of other factors that accelerated the growth of this ecosystem [7].

Malaysia is one of the developed countries in the world. The different anthropogenic activities have led to the degradation of the mangrove swamp area in Malaysia [8]. Natural disaster and awareness among the surrounding communities or public regarding the importance of the mangrove swamp ecosystem also contributing to this problem [7]. The restoration and rehabilitation of Kelantan Delta mangrove swamp forest was undertaken due to the ability of mangrove trees to reduce the sea wave's effect for protecting coastal area from being damaged. This is the cause for mangrove species that physiological and morphological adaptation to the water and nutrient enter into the mangrove tree. Therefore, the present study was undertaken to assess the water quality and sedimentary nutrients in Tumpat mangrove swamp forest. Several physico-chemical water quality parameters such as $\mathrm{pH}$, temperature, salinity, conductivity, dissolved oxygen (DO), biochemical oxygen demand (BOD), chemical oxygen demand (COD), total suspended solid (TSS), ammoniacal nitrogen $\left(\mathrm{NH}_{3} \mathrm{~N}\right)$ and Oil and Grease (OG) were tested in the study area. The objectives were to assess water quality and sedimentary nutrient status and establish their relationship to find out the sedimentary dynamic status. Water Quality Index (WQI) of the study area was compared with WQI value recommended by Department of Environment (DOE) Malaysia. The results of these findings provided the baseline data for sediments and water pollution in Tumpat mangrove forest.

\section{MATERIALS AND METHODS}

\section{Study Area}

This study was conducted in Tumpat mangrove swamp forest at Kelantan Delta of Malaysia. Five different islands namely Pulau Bedal (PB), Pulau Kambing (PK), Pulau Layang-layang (PL), Pulau Mas (PM) and Pulau Tujuh (PT) were situated at different locations started from coastal area to offshore. The Delta is located at Tumpat, on the north-east coast of Peninsular Malaysia $\left(6^{\circ} 11^{\prime}\right.$ to $6^{\circ} 13^{\prime} \mathrm{N} ; 102^{\circ} 9^{\prime}$ to $\left.102^{\circ} 14^{\prime} \mathrm{E}\right)$ [9]. The mean annual temperature and relative humidity of Kelantan and its surrounding environment was $26.8^{\circ} \mathrm{C}$ and $83.7 \%$ respectively [9], [10]. Fig. 1(a), (b), (c) and (d) showed the location of Kelantan in Malaysia, Tumpat district in Kelantan, studied islands in Tumpat, illustration of five surveyed islands indicating their position in Kelantan Delta, respectively.

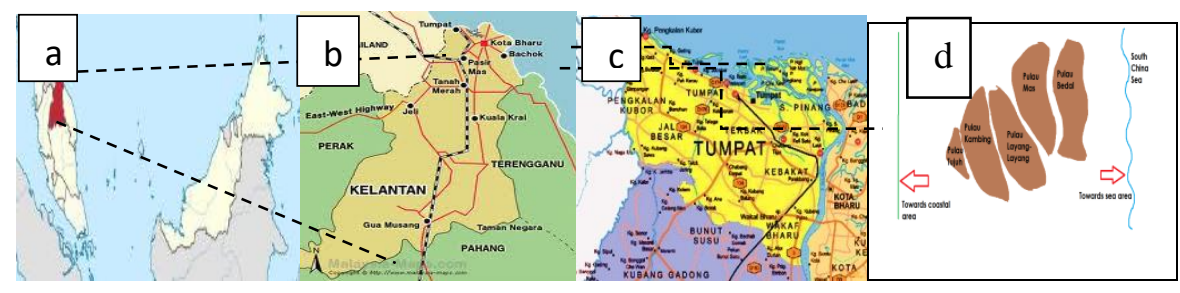

Figure 1: Map of the study area (a. Kelantan, Malaysia b.Tumpat, Kelantan c.Islands, Tumpat d. Illustration for islands location studied at Tumpat mangrove forest).

\section{Sampling and Analysis of Water Sample}

Water and sediment samples were collected between March to April 2013 from Tumpat mangrove swamp forest. Fifteen sampling stations three from each island were selected for this study. Three replicate samples were collected from each sampling station. A total of 90 samples ( 45 for water quality and 45 for sediment sample) were collected. Ten physicochemical properties were analyzed of water samples. A respective preservation chemical was added in order to preserve the content of each sample for each parameter for holding time. In case of sediment samples, the zipped-lock plastic bags were used to keep the collected samples. The plastic bags were pre-washed with distilled water and $70 \%$ ethanol. Water and sedimentary samples were collected from each station simultaneously. All bottles were carefully labeled and numbered prior to transport and kept at low temperature $\left(\leq 4^{0} \mathrm{C}\right)$. Physical parameters such as temperature, $\mathrm{pH}$, salinity, conductivity, and dissolved oxygen were measured immediately by using a multi-parameter (YSI 556) whereas BOD was measured Dilution Method (Standard Methods by APHA, AWWA, WEF, 21 ${ }^{\text {st }}$ Edition) and COD was 


\section{Assessment of Water Quality and Sedimentary Nutrient Status of Tumpat Mangrove Swamp Forest at Kelantan Delta, Malaysia}

measured Reactor Digestion Method (Jirka and Carter, 1975) in the laboratory of University Malaysia Kelantan (UMK), Malaysia. Ammoniacal nitrogen was measured by Nesslerization Method (Standard Methods by APHA, AWWA, WEF, $21^{\text {st }}$ Edition) and the $\mathrm{NH}_{3}-\mathrm{N}$ content was determined using spectrophotometer. Hexane Extractable Gravimetric Method used for testing OG and TSS was measured by Filtration Method (Standard Methods by APHA, AWWA, WEF, $21^{\text {st }}$ Edition).

\section{Sediment Sample Analysis}

Five sedimentary nutrients such as Calcium (Ca), Magnesium (Mg), Nitrogen (N), Phosphorus (P) and Potassium (K) were tested for collected sediment sample. Among them, $\mathrm{Ca}, \mathrm{Mg}$ and $\mathrm{K}$ were tested in the UMK laboratory; $\mathrm{N}$ and $\mathrm{P}$ were tested in the laboratory of Agricultural Department, Kota Bharu, Malaysia. Sediment samples were air dried in the laboratory and sieved through $6 \mu \mathrm{m}$ mesh sieve before analysis. Atomic Absorption Spectrophotometer (AAS-Perkin-Elmer-3300) (AAS) was used to determine $\mathrm{Ca}, \mathrm{Mg}$ and $\mathrm{K}$ nutrients. $\mathrm{P}$ and $\mathrm{N}$ were tested by Bray 2 Method (Berg and Gardner, 1978) and Kjedahl Digestion Method (Margestion, 2010), respectively.

\section{RESULTS AND DISCUSSION}

\section{Physical Properties of Water Samples}

The changes of the mangrove ecosystem are encompassed by physical changes, loss area associated with agricultural and urban development, increased industrial wastewater discharge into the water body entering the respected ecosystem. Water in the mangrove swamp forest is brackish that contained less salt than sea water. The swamps act as buffer as it separates sea water with the brackish water. The water chemistry in mangrove forest changes in three ways. Firstly, sewage discharged increased the nutrient load and the organic components, led to low dissolved oxygen [11]. Secondly, the discharged of heavy metals and pollutants brings to further degradation of water quality [12]. Thirdly, toxicological problems that come from organic micro-pollutants concentrated in the water [13].

The results revealed that the mean concentration of dissolved oxygen (DO), electrical conductivity and $\mathrm{pH}$ were $4.67 \pm 0.13 \mathrm{mg} / \mathrm{L}, 20.49 \pm 4.71 \mu \mathrm{S} / \mathrm{cm}$, and $8.32 \pm 0.06$ and these were ranged from $4.47-4.87$ $\mathrm{mg} / \mathrm{L}, 14.21-28.67 \mu \mathrm{S} / \mathrm{cm}, \quad$ and $8.24-8.42$ respectively. The results showed that the DO values of the present study were not too low or too high. This indicated that the presence of organic matter was less in Tumpat mangrove swamp forest. Hence, an assumption was made in which the DO concentration of each island was not affected by the factor of organic matter availability. Similar trends of results were obtained for the salinity in Tumpat mangrove forest. Conductivity and salinity are closely related to each other in which higher conductivity values indicate the presence of higher content of dissolved salts in the water [14]. Difference of $\mathrm{pH}$ value between the islands was less. According to Todd [15], $\mathrm{pH}$ value was decreased by organic acid from decayed vegetation. This indicated that the $\mathrm{pH}$ value of the present study was not affected by this factor. As Tumpat mangrove forest was newly planted area since 2004, the planted trees were still young, thus less decaying process occurred. The mean temperature of water in Tumpat mangrove forest was $30.04 \pm 0.32^{\circ} \mathrm{C}$. The temperature values were varied among the island ranged from 29.50$30.50^{\circ} \mathrm{C}$. Small variations of the temperature values resulted that the canopy structures were similar for each individual island. Therefore, intensity of sunlight radiation and evaporation had influenced surface water temperature [16].

\section{Chemical Properties of Water Samples}

The water is also being affected by pollutants which come from anthropogenic activities. These can be oil spillage from boat, landfill, and agricultural practices. Mastaller [17] mentioned that oil pollution both from petroleum production and accidental spills can destruct forest ecosystem extremely. The mean concentration of BOD, COD and OG are 1.09 \pm $0.13 \mathrm{mg} / \mathrm{L}, \quad 70.93 \pm 25.21 \mathrm{mg} / \mathrm{L}$ and $91.77 \pm$ $68.16 \mathrm{mg} / \mathrm{L}$ respectively and the values are ranged from $0.90-1.25 \mathrm{mg} / \mathrm{L}, \quad 44.33-120 \mathrm{mg} / \mathrm{L}$ and 18.67 $205.71 \mathrm{mg} / \mathrm{L}$ at PB, PL, PK, PM and PT respectively in the study area. The variations for BOD concentration among the islands were relatively low. Amadi et al., [18] reported that the BOD is a measure of oxygen used by microorganism to decompose waste (aerobic condition). As mentioned, that Tumpat mangrove forest was a newly planted area, there were less amount of organic waste produced by the forest, thus present of bacteria working to decompose this waste were also less. In this case, the demand for oxygen was low (due to all the bacteria) and might influence the low BOD concentration for the present study. Highest COD value was obtained from PL (120.00mg/L). Similar trends of results were obtained for Ammoniacal Nitrogen $\left(\mathrm{NH}_{3} \mathrm{~N}\right)$ in the study area. $\mathrm{COD}$ and $\mathrm{NH}_{3} \mathrm{~N}$ are closely related 


\section{Assessment of Water Quality and Sedimentary Nutrient Status of Tumpat Mangrove Swamp Forest at Kelantan Delta, Malaysia}

because the sources for both target parameters was organic matter/waste, thus showed similar trends of concentration values. As PL is the largest island while PT was the smallest one, the number of planted trees is corresponded to the area of the island. Therefore, the amounts of organic matter/waste were found highest at $\mathrm{PL}$ produced the highest concentration values of COD and $\mathrm{NH}_{3} \mathrm{~N}$. There was a large variation of OG concentration among each island. The highest $\mathrm{OG}$ concentration was found at PB $(205.71 \mathrm{mg} / \mathrm{L})$ which is situated nearest to the sea, and the lowest OG concentration was found at PT $(18.67 \mathrm{mg} / \mathrm{L})$ which is situated nearest to the coastal area. The distance difference of each island from the sea area possibly influenced the value of OG concentration of the present study. The study area was polluted with oil and grease due to the boating activities occurred at the sea and also in the mangrove bay. The values of TSS from each island were ranged widely from $62-218.50 \mathrm{mg} / \mathrm{L}$ with mean concentration of $114.57 \pm 13.81 \mathrm{mg} / \mathrm{L}$. The highest TSS concentration at PB was higher because this island was situated nearest to the coastal area, the water was trapped by sewage and waste produced from fish chip factory which was situated in front of PT. Although PL was situated far from the coastal area, this island also has high TSS concentration after PT. This might be due to as it was the largest island, thus it contains the highest amount of decaying plant and animal matter that trapped into the water.

Water Quality Index (WQI) and Classification of Tumpat Mangrove Swamp Forest

WQI value for Tumpat mangrove swamp forest was calculated by considering six water quality parameters mean values such as DO, BOD, COD, $\mathrm{pH}, \mathrm{NH}_{3} \mathrm{~N}$ and TSS. Firstly, the values were converted to Sub-Indices according to the equation guided by DoE. Then, the WQI was derived from the calculation provided by DoE as follows:

$\mathrm{WQI}=(0.22 * \mathrm{SIDO})+(0.19 * \mathrm{SIBOD})+(0.16 * \mathrm{SICOD})+$ $(0.15 *$ SIAN $)+(0.16 *$ SISS $)+(0.12 * \mathrm{pH})$

According to Table 1, WQI value of PB, PL, PM, PK and PT was 81.52, 59.65, 64.87, 66.23 and 64.73 respectively. PL was the most polluted island in Tumpat mangrove swamp forest. This might be due to its location was in the middle between sea and coastal area. Thus, it received much effects from pollutants come from both areas compared to another islands.

Table 1: WQI Value and Classification for Each Studied Island

\begin{tabular}{|l|l|l|}
\hline $\begin{array}{l}\text { Sample location } \\
\text { (Islands) }\end{array}$ & $\begin{array}{l}\text { WQI } \\
\text { Value }\end{array}$ & Classification \\
\hline $\begin{array}{l}\text { Pulau Bedal } \\
\text { (PB) }\end{array}$ & 81.52 & Class II(Clean) \\
\hline $\begin{array}{l}\text { Pulau Layang- } \\
\text { Layang (PL) }\end{array}$ & 59.65 & Class III (Polluted) \\
\hline Pulau Mas (PM) & 64.87 & $\begin{array}{l}\text { Class III (Slightly } \\
\text { polluted) }\end{array}$ \\
\hline $\begin{array}{l}\text { Pulau Kambing } \\
\text { (PK) }\end{array}$ & 66.23 & $\begin{array}{l}\text { Class III (Slightly } \\
\text { polluted) }\end{array}$ \\
\hline $\begin{array}{l}\text { Pulau Tujuh } \\
\text { (PT) }\end{array}$ & 64.73 & $\begin{array}{l}\text { Class III (Slightly } \\
\text { polluted) }\end{array}$ \\
\hline
\end{tabular}

The WQI value of the present study (Tumpat mangrove swamp forest) was as follows:

$\mathrm{WQI}=(0.22 * 64.405)+(0.19 * 95.789)+(0.16 * 30.985)+($

$0.15 * 49.554)+(0.16 * 33.58)+(0.12 * 85.772)$

$=60.43$

A value of DO, BOD, COD, $\mathrm{pH}, \mathrm{NH}_{3} \mathrm{~N}$, TSS and WQI found in Tumpat mangrove swamp forest were compared with the value provided by DoE (Table 2). WQI value for the Tumpat mangrove swamp forest was 60.43, falls under Class III which was slightly polluted according to the water classification provided by DoE. For the other parameters, $\mathrm{pH}$ falls under Class I, BOD falls under Class II, TSS and DO falls under Class III, and COD and $\mathrm{NH}_{3} \mathrm{~N}$ falls under Class IV. 
Assessment of Water Quality and Sedimentary Nutrient Status of Tumpat Mangrove Swamp Forest at Kelantan Delta, Malaysia

Table 2: Comparison with DOE Water Quality Index and Classification

\begin{tabular}{|c|c|c|c|c|c|c|c|}
\hline \multirow[b]{2}{*}{ PARAMETER } & \multirow[b]{2}{*}{ UNIT } & \multicolumn{5}{|c|}{ CLASS } & \multirow{2}{*}{$\begin{array}{l}\text { Present Study } \\
\text { (Tumpat } \\
\text { mangrove } \\
\text { swamp } \\
\text { forest) }\end{array}$} \\
\hline & & I & II & III & IV & $\mathrm{V}$ & \\
\hline $\mathrm{NH}_{3} \mathrm{~N}$ & $\mathrm{mg} / \mathrm{L}$ & $<0.1$ & $0.1-0.3$ & $0.3-0.9$ & $0.9-2.7$ & $>2.7$ & 0.94 \\
\hline BOD & $\mathrm{mg} / \mathrm{L}$ & $<1$ & $1-3$ & $3-6$ & $6-12$ & $>12$ & 1.09 \\
\hline COD & $\mathrm{mg} / \mathrm{L}$ & $<10$ & $10-25$ & $25-50$ & $50-100$ & $>100$ & 70.93 \\
\hline $\mathrm{DO}$ & $\mathrm{mg} / \mathrm{L}$ & $<7$ & $5-7$ & $3-5$ & $1-3$ & $<1$ & 4.67 \\
\hline $\mathrm{pH}$ & & $>7.0$ & $6.0-7.0$ & $5.0-6.0$ & $<5.0$ & $>5.0$ & 8.32 \\
\hline TSS & $\mathrm{mg} / \mathrm{L}$ & $<25$ & $25-5$ & $50-150$ & $150-300$ & $>300$ & 114.57 \\
\hline WQI & & $>92.7$ & $76.5-92.7$ & $51.9-76.5$ & $31.0-51.9$ & $<31.0$ & 60.43 \\
\hline
\end{tabular}

\section{Analysis of Variance (ANOVA) for Water Samples}

ANOVA test was performed in the study determining the significant effects of different islands. The dependent variables are the value of each water quality parameter, while the different islands are the explanatory variables. It was considered to be not significant when the value of probability of significance (p) was greater than 0.05 . From the table 3 it is suggested that the different location of the island influenced the reading of each water quality parameters. Further analysis using one-way ANOVA method yielded two results. There were a significant different in the six parameter values between the five islands, such as conductivity $(\mathrm{p}<0.011), \mathrm{pH} \quad(\mathrm{p}<0.001)$, temperature $(p<0.004)$, salinity $(p<0.009)$, COD $(p<0.001)$, and oil and grease $(p<0.000)$. Another result obtained included there were no significant difference in the four parameter values between the five islands such as DO ( $p<0.301)$, BOD $(\mathrm{p}<0.351)$, $\mathrm{NH}_{3} \mathrm{~N}(\mathrm{p}<0.062)$, and TSS $(\mathrm{p}<0.767)$. Therefore, it can be concluded that the location of the five islands have significant influenced on the value of $\mathrm{pH}$, temperature, salinity, COD and OG.

\section{Correlation Analysis between Physico-Chemical Properties of Water Samples}

Coefficient of correlation (r) was done to understand the relationship between the physicochemical parameters of the water samples. Using the Pearson's correlation method, analysis of ten physico-chemical parameters revealed that there was a significant and positive relationship between conductivity: $\mathrm{pH}(\mathrm{r}=0.784)$, conductivity: salinity $(\mathrm{r}=1.000)$, conductivity: COD $(\mathrm{r}=0.952)$ and conductivity: $\mathrm{NH}_{3} \mathrm{~N}(\mathrm{r}=0.672)$ at 0.01 level of significance. Conductivity also has strong correlation with oil and grease $(\mathrm{r}=0.534)$ at the 0.05 level of significance. For $\mathrm{pH}$, the strongest correlation was found between $\mathrm{pH}$ : salinity $(\mathrm{r}=0.783), \mathrm{pH}$ : COD ( $\mathrm{r}=0.844)$, and $\mathrm{pH}: \mathrm{NH} 3 \mathrm{~N}$ $(r=0.697)$. For temperature, it revealed a negative relationship with oil and grease with $(r=-0.678)$. Salinity shows a significant and positive relationship with $\mathrm{COD}(\mathrm{r}=0.954), \mathrm{NH}_{3} \mathrm{~N}$ ( $\mathrm{r}=$ $0.681)$, and oil grease $(r=0.551)$. Finally, COD shows a strong positive relationship with $\mathrm{NH}_{3} \mathrm{~N}(\mathrm{r}=$ $0.775)$.

Table 3: ANOVA for water physico-chemical properties

\begin{tabular}{|c|c|c|}
\hline $\begin{array}{c}\text { Physico-chemical } \\
\text { Properties }\end{array}$ & F Value & $\begin{array}{c}\text { Significance } \\
\text { value }\end{array}$ \\
\hline DO & 1.406 & 0.301 \\
\hline Conductivity & 5.871 & 0.011 \\
\hline $\mathrm{pH}$ & 10.467 & 0.001 \\
\hline Temperature & 7.892 & 0.004 \\
\hline Salinity & 6.148 & 0.009 \\
\hline $\mathrm{BOD}$ & 1.250 & 0.351 \\
\hline $\mathrm{COD}$ & 11.365 & 0.001 \\
\hline $\mathrm{NH}{ }_{3} \mathrm{~N}$ & 3.197 & 0.062 \\
\hline $\mathrm{OG}$ & 38.992 & 0.000 \\
\hline $\mathrm{TSS}$ & 0.456 & 0.767 \\
\hline
\end{tabular}


Table 4: The Pearson's Correlation Coefficient Analysis between Physico-Chemical Properties. $(\mathrm{N}=15)$

\begin{tabular}{|c|c|c|c|c|c|c|c|c|c|c|}
\hline & DO & COND. & $\mathrm{pH}$ & TEMP. & SALINITY & BOD & COD & $\mathrm{NH}_{3} \mathrm{~N}$ & OG & TSS \\
\hline DO & 1 & -.291 & -.192 & -.168 & -.291 & -.332 & -.399 & -.461 & -.105 & -.106 \\
\hline COND. & & 1 & $.784 * *$ & -.447 & $1.000 * *$ & .260 & $.952 * *$ & $.672 * *$ & $.534 *$ & -.005 \\
\hline $\mathrm{pH}$ & & & 1 & -.173 & $.783 * *$ & .221 & $.844 * *$ & $.697 * *$ & .461 & -.011 \\
\hline TEMP. & & & & 1 & -.469 & -.331 & -.391 & -.267 & $-.678 * *$ & -.010 \\
\hline SALINITY & & & & & 1 & .274 & $.954 * *$ & $.681 * *$ & $.551 *$ & -.008 \\
\hline BOD & & & & & & 1 & .318 & .383 & .329 & -.019 \\
\hline COD & & & & & & & 1 & $.775 * *$ & .511 & -.031 \\
\hline $\mathrm{NH}_{3} \mathrm{~N}$ & & & & & & & & 1 & .389 & .079 \\
\hline $\mathrm{OG}$ & & & & & & & & & 1 & -.143 \\
\hline
\end{tabular}

$* *$ Correlation is significant at the 0.01 level (2-tailed)

*Correlation is significant at the 0.05 level (2-tailed)

\section{Nutrient Status for Sediment Samples}

The major water pollution problem is sedimentation that is associated with contaminants and heavy metals, thus affecting the quality of the water being entered. Nutrient supply was very important for tree to promote tree growth and forest performance. For the present study, different macronutrients of sediment samples $(\mathrm{N}, \mathrm{P}, \mathrm{K}, \mathrm{Mg}$, and $\mathrm{Ca}$ ) were measured in Tumpat mangrove swamp forest. Mean percentage of $\mathrm{N}, \mathrm{P}, \mathrm{K}$, and Cawere $0.41 \pm 0.04 \%, 4.66 \pm 2.09 \mathrm{mg} / \mathrm{L}, 50.61 \pm$ $10.58 \mathrm{mg} / \mathrm{L}$ and $83.15 \pm 11.78 \mathrm{mg} / \mathrm{L}$, respectively, where the value ranged from $0.36-0.49 \%, 2.14-8.33$ $\mathrm{mg} / \mathrm{L}, 34.25-69.4 \mathrm{mg} / \mathrm{L}$ and 66.71-104.18 mg/L among the islands. The highest $\mathrm{N}$ value was found from PT which was the nearest island to coastal area. Deposition of litter from human settlement and fish chip factory might be the reason for the high $\mathrm{N}$ value at PT although this was the smallest island. This indicated that the percentage of $\mathrm{N}$ value was not affected by the availability of organic matter. The trend of the $\mathrm{P}$ concentration for the present study was decreased from sea to coastal area. Therefore, it can be concluded that intrusion of seawater into the mangrove bay possibly had influenced the $\mathrm{P}$ concentration in the sediment as $\mathrm{P}$ was available from oceanic input. The results showed that PB had the highest $\mathrm{K}$ concentration and PT had the lowest one. Similar trends of results were obtained for $\mathrm{Mg}$ in Tumpat mangrove swamp forest. This revealed that the effects of seawater might influenced on the concentration of both target parameter because the highest values were obtained from island that was nearest to the sea area $(\mathrm{PB})$, and the lowest from island nearest to coastal area (PT). The results showed a different trend from $\mathrm{K}$ and $\mathrm{Mg}$ status. Probably, the concentration of $\mathrm{Ca}$ value was not influenced by seawater intrusion specifically because of the highest $\mathrm{Ca}$ concentration was not found at $\mathrm{PB}$

which was the nearest island to the sea area. PL the largest island, was found to have the highest concentration of $\mathrm{Ca}$ value. This might due to high number of gastropods which commonly known as snails and slugs. The gastropods have shells which made up by calcium carbonate. The $\mathrm{Ca}$ might deposit in the sediment during the decomposition of the gastropods.

\section{Analysis of Variance (ANOVA) for Sediment Samples}

ANOVA test was performed in the study to determine the significant effects of sedimentary nutrients. The different islands are the fixed factor, while dependent variables are the value of each sedimentary nutrient. If the value of probability of significance (p) was greater than 0.05 , it was considered not significant.

\section{Correlation Analysis between Sedimentary Nutrients}

Coefficient of correlation (r) was performed to understand the relationship between the nutrient values of the sediment samples. Using the Pearson's correlation method, the results of the analysis were summarized in Table 5.

Table 5: The Pearson's correlation coefficient analysis between sedimentary nutrients

\begin{tabular}{|c|c|c|c|c|c|}
\hline Nutrients & $\mathrm{N}$ & $\mathrm{P}$ & $\mathrm{K}$ & $\mathrm{Ca}$ & $\mathrm{Mg}$ \\
\hline $\mathrm{N}$ & 1 & -0.239 & $-0.556^{*}$ & -0.244 & -0.453 \\
\hline $\mathrm{P}$ & & 1 & 0.449 & 0.106 & 0.514 \\
\hline $\mathrm{K}$ & & & 1 & -0.136 & $0.845^{* *}$ \\
\hline $\mathrm{Ca}$ & & & & 1 & 0.045 \\
\hline $\mathrm{Mg}$ & & & & 1 \\
\hline **Correlation is significant at the 0.01 level (2-tailed) \\
*Correlation is significant at the 0.05 level (2-tailed)
\end{tabular}


Analysis of five sedimentary nutrients revealed that there was a significant and positive relationship between $\mathrm{K}$ and $\mathrm{N}(\mathrm{r}=0.556)$ at 0.05 level of significance. The strongest positive relationship was found between $\mathrm{Mg}$ and $\mathrm{K}(\mathrm{r}=0.845)$. In spite of this, there were very small values and negative correlation between $\mathrm{N}: \mathrm{P}(\mathrm{r}=-0.239), \mathrm{N}: \mathrm{Ca}(\mathrm{r}=-$ $0.244), \mathrm{N}: \mathrm{Mg}(\mathrm{r}=-0.453)$, and $\mathrm{K}: \mathrm{Ca}(\mathrm{r}=-0.136)$. Moreover, there were positive correlation with very small values between P:K $(r=0.449), \mathrm{P}: \mathrm{Ca} \quad(\mathrm{r}=$ 0.106) and $\mathrm{Ca}: \mathrm{Mg}(\mathrm{r}=0.045)$.

\section{Correlation Analysis between Water Physico- Chemical Parameter and Sedimentary Nutrient}

Correlation analysis was carried out to determine the relationship between water physico-chemical parameters and sedimentary nutrients. By using the Pearson's correlation method, the results of the analysis were summarized in Table 6 .

Table 6: The Pearson's Correlation Coefficient Analysis between Water Physico-Chemical Parameter and Sedimentary Nutrient

\begin{tabular}{|l|c|c|c|c|c|c|c|c|c|c|}
\hline & BOD & COD & $\mathrm{NH}_{3} \mathrm{~N}$ & OG & TSS & DO & COND. & PH & TEMP & SALINITY \\
\hline $\mathrm{N}$ & -.222 & -.090 & -.196 & -.221 & -.340 & -.243 & -.115 & -.029 & .112 & -.117 \\
\hline $\mathrm{P}$ & .043 & .273 & $.557^{*}$ & $.518^{*}$ & -.205 & .415 & .315 & .114 & -.342 & .326 \\
\hline $\mathrm{K}$ & .366 & .344 & .383 & $.678^{* *}$ & -.040 & .381 & .328 & $-.705^{* *}$ & -.112 & .432 \\
\hline $\mathrm{Ca}$ & .324 & .278 & .328 & .195 & .031 & -.508 & .121 & .097 & -.003 & .126 \\
\hline $\mathrm{Mg}$ & .400 & .429 & .377 & $.721^{*}$ & -.338 & .122 & .520 & .428 & -.450 & .530 \\
\hline
\end{tabular}

Analysis between both of the variables depicted that there were three patterns of correlation. A significant and positive relationship were found between $\mathrm{P}$ : $\mathrm{NH}_{3} \mathrm{~N}(\mathrm{r}=0.557)$ and $\mathrm{P}$ : O\&G $(r=0.518)$ at 0.05 level of significance. In addition, there was the strongest relationship between $\mathrm{K}$ : O\&G ( $\mathrm{r}=0.678)$ and $\mathrm{Mg}$ : O\&G ( $\mathrm{r}=$ 0.721). However, a strong negative correlation found between $\mathrm{Ca}$ : temperature $(\mathrm{r}=-\mathrm{0.705})$. These results concluded that the different concentration of the physico-chemical properties had influenced the different values for sedimentary nutrients at Tumpat mangrove swamp forest area. Thus, we presumed that water has effects on sediment, and influenced the nutrient status. Moreover, the sediment of the study area was not dynamic because most of the nutrient $(\mathrm{P}, \mathrm{K}$, and $\mathrm{Mg}$ ) were influenced by the concentration of oil and grease values.

\section{CONCLUSION}

The research resulted physical and chemical properties of water quality as well as the status of the sedimentary nutrients of the study area. Pertinently, the different location of each studied islands has given the different values for each tested parameter. Based on the research, the major findings are the water quality index (WQI) of the study was found to be 60.43. According to WQI and classification provided by DoE, water quality of Tumpat mangrove swamp forest falls under Class 3. It means the water quality of the present study was slightly polluted and the most polluted island was PL which was situated in the middle between sea and coastal area. Pollutants come from both areas and this was the main reason that this island was highly polluted. The pollutant composition trend of different islands was OG $>$ COD $>$ TSS $>$ BOD $>\mathrm{NH}_{3} \mathrm{~N}$, OG $>$ COD $>$ TSS $>\mathrm{N}$ $\mathrm{H}_{3} \mathrm{~N}>\mathrm{BOD}, \mathrm{COD}>\mathrm{TSS}>\mathrm{OG}>\mathrm{NH}_{3} \mathrm{~N}>\mathrm{BOD}, \mathrm{TSS}>\mathrm{C}$ $\mathrm{OD}>\mathrm{OG}>\mathrm{BOD}>\mathrm{NH}_{3} \mathrm{~N}$ and $\mathrm{TSS}>\mathrm{COD}>\mathrm{OG}>\mathrm{BOD}$ $>\mathrm{NH}_{3} \mathrm{~N}$ for $\mathrm{PB}, \mathrm{PL}, \mathrm{PM}, \mathrm{PK}$ and $\mathrm{PT}$ respectively. The final result indicated that availability of organic matter might be one of the influential factors for the influence of $\mathrm{DO}, \mathrm{BOD}, \mathrm{COD}$, $\mathrm{NH}_{3} \mathrm{~N}$, and $\mathrm{N}$ value in Tumpat mangrove swamp forest. Sedimentary nutrient status of the study was not dynamic because most of the nutrients $(\mathrm{P}, \mathrm{K}$, and $\mathrm{Mg}$ ) were affected by oil and grease pollution.

\section{ACKNOWLEDGEMENT}

The authors acknowledge the Agricultural Department of Kota Bharu, Kelantan to provide the laboratory facilities to accomplish the research work. The authors also acknowledge the Faculty of Earth Science, University Malaysia Kelantan, Malaysia for hosting this research work under student research project.

\section{CONFLICT OF INTEREST}

The authors declared that there is no conflict of interest.

\section{REFERENCES}

[1]Jusoff, K. (2008) Managing sustainable mangrove forest in Peninsular Malaysia. Journal of sustainable development, 1.

[2] Hamilton, S.E., Casey, D., (2016) Creation of a high spatio-temporal resolution global database 
of continuous mangrove forest cover the $21 \mathrm{st}$ centuary (CGMFC-21), Glob. Ecol. Biogeogr. 25, 729-738.

[3] Bulmer, R.H., Schwendenmann, L., Lohrer, A.M., Lundquist, C.J.(2017) Sediment carbon and nutrient fluses from cleared and impact temperate mangrove ecosystems and adjacent sandflats, Science of the Total Environment, Retrived from http://dx.doi.org/10.1016/j.scitoenv.2017.05.13 9 (Acess on 18 July 2018).

[4] Duke, N. C., Ball, M. C., \& Ellison, J. C. (1998) Factors influencing biodiversity and distributional gradients in mangroves. Glob. Ecol. Biogeogr. Letters. 7, 27-47.

[5] Tam, N. E. Y., Wong, Y.S. (2000) Spatial variation of heavy metals in surface sediments of Hong Kong mangrove swamps. Environ. Pollut. 110, 195-205.

[6] Liu, J., et al. (2017) Relative influence of sediment variables on mangrove community assembly in Leizhou Peninsula, China, Marine Pollution

Bulletin http://dx.doi.org/10.1016/j.marpolbul.2017.02.0 03

[7] Lovelock, C. E., Ball, M. C., Martin, K. C., and Feller, L. C. (2009) Nutrient enrichment increases mortality of mangrove. PloS ONE 4(5): $\quad$ e5600. doi: 10.1371/journal.pone.0005600.

[8] Dodd, R. S., \& Ong, J. E., (2008) Future of mangrove ecosystem. In Nicholas V. C. Polunin. (Eds.), Aquatic ecosystems, trends and global prospects (pp. 172). United States of America: Cambridge University Press, New York.

[9] Satyanarayana, B., Mohamad, K. A., Idris, I. F., Husain, M. L., \& Guebas F. D. (2009) Assessment of mangrove vegetation based on remote sensing and ground-truth measurements at Tumpat, Kelantan Delta, East Coast of Peninsular Malaysia. Inter. Journal of Remote Sensing, 32 (6), 1635-1650.
[10] Kasawani, I. (2003) Mapping and distribution of the Kelantan Delta mangroves using remote sensing and ground data. M. Sc. Thesis, University College of Science and Technology Malaysia (KUSTEM), Kuala Terengganu, Malaysia. pp. 199.

[11] Damme, S. V., Ysebaert, T., Meiri, P., Bergh, E. V. D., (1999). Habitatstruturen, waterkwaleteit en leefgemeenschappen in the Schelde-estuarium. (Report Instituut voor Natuurbehoud 99/24) Instituut voor Natuurbehoud, Brussels.

[12] Walling, D. E., Owens, P. N., Carter, J., Leeks G. J. L., Lewis, S., Meharg, A. A., \& Wright, J. (2003). Storage of sediment-associated nutrients and contaminants in river channel and floodplain systems. Appliied Geochem, 18, 195220.

[13] Jonkers, N., Laane, RWPM., De Voogt, P. (2003). Fate of nonylphenol ethoxylates and their metabolites in two Dutch estuaries: evidence of biodegradation in the field. Environmental Science Technology, 37, 321327.

[14] Abdullah, M. H. and B. Musta, (1999) Phreatic Water Quality of the Turtle Island of West Malaysia: Pulau Selingan and Pulau Bakungan Kechil. Borneo Science, 6:1-9.

[15] Todd, D. K., (1980) Groundwater Hydrology, 2nd Edn., John Wiley and Sons, New York.

[16] Govindasamy, C., L. Kannan and Jayapaul, A. (2000) Seasonal variation in physico-chemical properties and primary production in the coastal water biotopes of Coromandel Coast, India. J. Environ. Biol., 21, 1-7.

[17] Mastaller, M. (1996). Destruction of mangrove wetlands-causes and consequences. Natural Resources and Development, 43(44), 37-57.

[18] Amadi, A.N., P.I. Olasehinde, E.A. Okosun and J. Yisa, (2010) Assessment of the Water Quality Index of Otamiri and Oramiriukwa Rivers. Phys. Int., 1:116-123. DOI: 10.3844/pisp.2010.116.12. 
Assessment of Water Quality and Sedimentary Nutrient Status of Tumpat Mangrove Swamp Forest at Kelantan Delta, Malaysia 